\title{
Potensi Penangkapan Radikal Bebas DPPH dari Ekstrak Mengkudu (Morinda citrifolia L), Kelor (Moringa oleifera) dan Kedondong Hutan (Spondias pinnata (l.f) kurz)
}

\author{
Satriari, P.R. ${ }^{1}$, Vedawati, P.P.K. ${ }^{1}$, Primantara, M. ${ }^{1}$, Warditiani, N.K. ${ }^{1}$, I.M.A. Gelgel Wirasuta ${ }^{1}$, \\ Susanti, N.M.P. ${ }^{1}$ \\ ${ }^{1}$ Jurusan Farmasi-Fakultas MIPA-Universitas Udayana \\ Korespondensi: Ni Putu Rika Satriari \\ Jurusan Farmasi-Fakultas Matematika dan Ilmu Pengetahuan Alam-Universitas Udayana. \\ Jalan Kampus Unud-Jimbaran, Jimbaran-Bali, Indonesia 80364 Telp/Fax: 0361-703837 Email: \\ satriaririka@gmail.com
}

\begin{abstract}
ABSTRAK
Reactive Oxygen Species (ROS) merupakan suatu produk alami yang terbentuk dari metabolisme aerobik normal dalam tubuh yang secara potensial dapat menyebabkan kerusakan. Penelitian bertujuan untuk mengetahui potensi antioksidan yang paling kuat dari ekstrak buah mengkudu (Morinda citrifolia L), ekstrak daun kelor (Moringa oleifera) dan ekstrak daun kedondong hutan (Spondias pinnata (1.f) kurz). Pengujian aktivitas antioksidan dari ketiga tanaman ini yaitu dilakukan dengan metode DPPH yang kemudian diamati dengan Spektro UV-Vis pada panjang gelombang maksimum $315 \mathrm{~nm}$. Analisis data dilakukan dengan menghitung persen inhibisi (\% inhibisi) yang kemudian dibuat persamaan regresi linear. Hasil yang diperoleh bahwa nilai $\mathrm{IC}_{50}$ ekstrak buah mengkudu yaitu $22,95 \mu \mathrm{g} / \mathrm{mL}$, nilai $\mathrm{IC}_{50}$ dari ekstrak daun kelor yaitu $42,19 \mu \mathrm{g} / \mathrm{mL}$ sedangkan nilai IC $_{50}$ dari ekstrak daun kedondong hutan yaitu $49,97 \mu \mathrm{g} / \mathrm{mL}$
\end{abstract}

Kata Kunci : Mengkudu, Kelor, Kedondong Hutan, Antioksidan, $\mathrm{IC}_{50}$, DPPH

\section{PENDAHULUAN}

Reactive Oxygen Species (ROS) merupakan suatu produk alami yang terbentuk dari metabolisme aerobik normal dalam tubuh yang secara potensial dapat menyebabkan kerusakan (Benzie dan Strain, 1996). Radikal bebas yang dihasilkan dalam reaksi biokimia tubuh, terlibat sebagai mediator pada berbagai penyakit. ROS dalam jumlah yang berlebihan dapat menyerang molekul biologis yang selanjutnya dapat menyebabkan kerusakan sel atau jaringan, dan dihubungkan dengan berbagai penyakit degeneratif (Amarowicz dkk., 2004).

Antioksidan dapat menangkap radikal bebas dan mendetoksifikasinya (Kumaran dan Karunakaran, 2005). Antioksidan sintetik, seperti ter-butil hidroksitoluen (BHT) dan terbutil hidroksianisol (BHA), tersedia secara komersial, dan saat ini digunakan dalam proses industri. Namun, karena diduga sebagai promotor efek samping karsinogenesis dan efek negatif lainnya, maka penggunaan antioksidan sintetik dalam makanan, produk kosmetik, dan sediaan farmasi telah menurun. Belakangan ini, antioksidan alami yang berasal dari tanaman herbal menjadi pilihan masyarakat (Li dkk.,
2011). Tanaman yang dapat dimanfaatkan sebagai sumber antioksidan alami salah satunya adalah Kedondong hutan (Spondias pinnata (1.f) kurz), Mengkudu (Morinda citrifolia) dan Kelor (Moringa oleifera) Ketiga tanaman tersebut banyak dimanfaatkan oleh masyarakat sebagai obat tradisional dan mempunyai potensi sebagai antioksidan (Pitojo dan Sumiati, 2005).

Tujuan dilakukan penelitian ini untuk mengetahui potensi penangkapan radikal DPPH dari ekstrak etanol $96 \%$ buah mengkudu, kelor dan kedondong hutan, berdasarkan atas nilai $\mathrm{IC}_{50}$ untuk menentukan ekstrak yang berpotensi paling kuat sebagai antioksidan.

\section{BAHAN DAN METODE}

\subsection{Bahan}

Serbuk simplisia buah mengkudu (Morinda citrifolia) yang diperoleh dari daerah Badung, serbuk simplisia daun kelor (Moringa oleifera) yang diperoleh dari daerah Gianyar, serbuk simplisia daun kedondong hutan (Spondias pinnata (l.f) kurz) yang diperoleh dari daerah singaraja, etanol 96\%, metanol, 
Difenilpikril Hidrazil Hidrat (DPPH) ex. Sigma.

\subsection{Alat}

Rotary evaporator (Eyela ${ }^{\circledR}$ ) dan Spektro UV-Vis (UV-SHIMADZHU ${ }^{\circledR}$ ).

\subsection{Prosedur Kerja}

\subsubsection{Pembuatan Ekstrak}

Masing-masing serbuk simplisia ditimbang sebanyak 500 gram, dimasukkan ke dalam toples ditambahkan dengan 2,5 L etanol 96\% didiamkan selama 2 hari dengan sesekali diaduk. Residu yang diperoleh diremaserasi sebanyak 2 kali dengan menggunakan masingmasing 1,25 L etanol 96\%. Filtrat yang dieroleh dari masing-masing ekstrak digabung, pelarut diuapkan dengan evaporaty evaporator pada suhu $50^{\circ} \mathrm{C}$.

\subsubsection{Uji Aktivitas Antioksidan dengan DPPH}

\subsubsection{Pembuatan Larutan Stok DPPH}

Ditimbang 10 mg DPPH, dimasukkan ke dalam labu ukur $10 \mathrm{~mL}$, ditambahkan metanol p.a sampai tanda batas, kemudian dikocok hingga homogen.

\subsubsection{Larutan DPPH $(0,04 \mathrm{mg} / \mathrm{mL})$}

Untuk membuat larutan DPPH dengan kosentrasi $0,04 \mathrm{mg} / \mathrm{mL}$ dilakukan dengan cara pengenceran dari larutan stok $1 \mathrm{mg} / \mathrm{mL}$. Kemudian ditambahkan dengan metanol p.a hingga $100 \mathrm{~mL}$.

\subsubsection{Pengujian Aktivitas Antioksidan mengguakan Metode DPPH}

Ditimbang ekstrak masing-masing sebanyak 10 mg kemudian ditambahkan $10 \mathrm{~mL}$ metanol dan disonikasi selama 15 menit kemudian sampel dan standar dipipet sebanyak 10, 20, 30, 40 dan $50 \mu \mathrm{L}$ dan dimasukkan kedalam vial, kemudian ditambahkan metanol hingga $5 \mathrm{~mL}$. Dari masing-masing konsentrasi dipipet $1,5 \mathrm{~mL}$ dan dimasukkan ke dalam vial yang berbeda kemudian ditambahkan 1,5 mL larutan DPPH 0,04 mg/mL. Didiamkan vial selama 30 menit agar reaksi berjalan optimum, hindarkan kontak dengan cahaya. Kemudian diuji dengan Spektrofotometri UV-Vis pada $\lambda$ $315 \mathrm{~nm}$.

\subsubsection{Analisis Data}

Dihitung inhibisi (\% inhibisi) dengan rumus sebagai berikut:

$$
\begin{aligned}
& \% \text { Inhibisi }=\frac{(\text { Akontrol-Asampel })}{\text { Akontrol }} \times 100 \% \\
& \text { Keterangan: } \\
& \mathrm{A}_{\text {kontrol }}=\text { Absorbansi blangko } \\
& \mathrm{A}_{\text {sampel }}=\text { Absorbansi sampel }
\end{aligned}
$$

Selanjutnya hasil perhitungan dimasukkan ke dalam persamaan regresi linear. Nilai $\mathrm{IC}_{50}$ dari perhitungan pada saat \% inhibisi sebesar $50 \%$. $\mathrm{Y}=\mathrm{aX}+\mathrm{b}$ (Cahyana, 2002).

\section{HASIL}

3.1 Pembuatan ekstrak etanol $96 \%$.

Tabel 1. 1 Hasil rendemen ekstrak etanol 96 $\%$ buah mengkudu, kelor dan kedondong hutan

\begin{tabular}{llc}
\hline No & Nama ekstrak & \% rendemen \\
\hline 1 & Buah mengkudu & 8,2 \\
2 & Daun kelor & 7,39 \\
3 & Daun kedondong & 8,9 \\
& hutan & \\
\hline
\end{tabular}

\subsection{Uji aktivitas antioksidan}

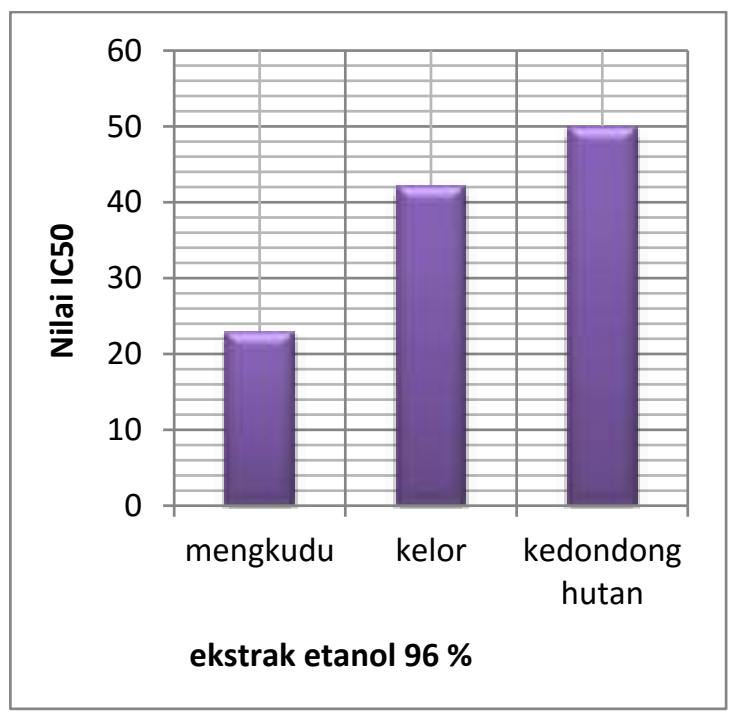

Gambar 1.1 Diagram nilai $\mathrm{IC}_{50}$ ekstrak etanol $96 \%$ buah mengkudu, kelor dan kedondong hutan

\section{PEMBAHASAN}

4.2 Pembuatan ekstrak etanol $96 \%$

Maserasi merupakan metode ekstraksi dengan pengerjaan dan peralatan yang sederhana sehingga mudah dilakukan. Serbuk buah mengkudu, kelor dan kedondong hutan 
dimaserasi selama 24 jam sambil sesekali diaduk. Ketika direndam, akan terjadi kontak antara larutan penyari dan serbuk sehingga zat aktif di dalam serbuk simplisia akan ditarik ke dalam pelarut (Anwar dkk., 2016). Berdasarkan hasil esktrasi diperoleh rendemen masingmasing sebesar 8,2 \%, 7,39\% dan 8,9\%. Rendemen merupakan perbandingan berat ekstrak yang dihasilkan dengan berat serbuk simplisia yang digunakan (Depkes RI, 2000). Semakin tinggi rendemen, semakin besar pula ekstrak yang dapat dihasilkan dari suatu serbuk simplisia.

\subsection{Pengujian Aktivitas Antioksidan}

Pengujian aktivitas antioksidan ekstrak etanol $96 \%$ buah mengkudu (Morinda citrifolia L), daun kelor (Moringa oliefera L) dan daun kedondong hutan (Sprodias pinnata) dilakukan dengan metode penangkapan radikal bebas 2,2difenil-1- pikrihidrazil (DPPH). Metode DPPH merupakan metode yang paling sering digunakan untuk menguji aktivitas antioksidan suatu tanaman. Antioksidan merupakan senyawa pemberi elektron (elektron donor) yang berperan dalam menghambat oksidasi yang diperantarai oksigen. Senyawa antioksidan dapat mencegah pengaruh buruk yang disebabkan oleh senyawa radikal bebas sehingga memegang peranan penting dalam pertahanan tubuh terhadap penyakit (Percival, 1998). Pada percobaan ini potensi penangkapan radikal bebas menggunakan metode DPPH (1,1-diphenyl-2 picrylehydrazyl). Metode DPPH merupakan suatu metode yang efektif dan cepat untuk memperkirakan aktivitas antiradikal dari suatu senyawa. Saat larutan DPPH dicampurkan dengan substansi yang dapat memberikan hidrogen radikal, akan menyebabkan terjadinya bentuk tereduksi dengan perubahan warna violet menjadi kuning (Molyneux, 2003) berikut adalah reaksi antara DPPH dengan antioksidan

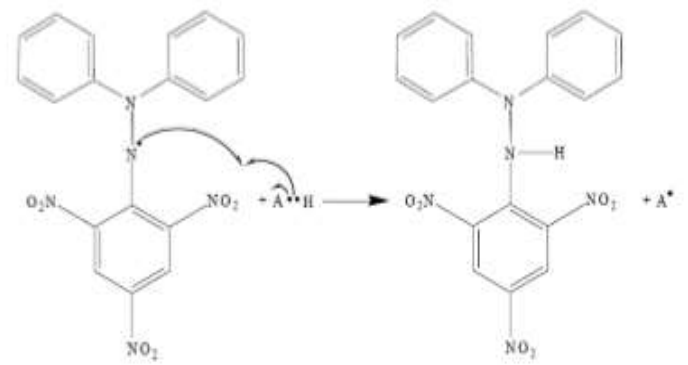

Gambar 1.2 Reaksi antara DPPH dengan antioksidan (Sayuti dkk., 2015).

Berdasarkan perhitungan nilai $\mathrm{IC}_{50}$ diperoleh nilai $\mathrm{IC}_{50}$ buah mengkudu sebesar $22,95 \mu \mathrm{g} / \mathrm{mL}$, daun kelor mempunyai aktivitas sebesar 42,19 $\mu \mathrm{g} / \mathrm{mL}$ dan daun kedondong hutan mempunyai aktivitas sebesar 49,97 $\mu \mathrm{g} / \mathrm{mL}$. Berdasarkan kategori ekstrak etanol 96\% buah mengkudu mempunyai nilai $\mathrm{IC}_{50}$ paling kuat $\left(\mathrm{IC}_{50}<50 \mu \mathrm{g} / \mathrm{mL}\right.$ ) sedangkan ekstrak etanol $96 \%$ daun kelor dan kedondong hutan memiliki aktivitas antioksidan yang lebih kecil. Hal ini dikarenakan pada buah mengkudu terdapat senyawa asam askorbat yang berpotensi sebagai antioksidan yang sangat kuat dan senyawa ini tidak terdapat pada daun kelor dan kedondong hutan. Senyawa ini mampu mendonorkan atom hidrogen kepada radikal bebas sehingga aktivitasnya dapat diukur menggunakan metode DPPH. Mekanisme senyawa ini hampir sama dengan vitamin E, yaitu mampu menangkap radikal bebas kemudian mencegah terjadinya terbentuuknya suatu reaksi berantai (Triyasmono dkk., 2016) Berikut adalah gambar reaksi asam askorbat dengan DPPH.

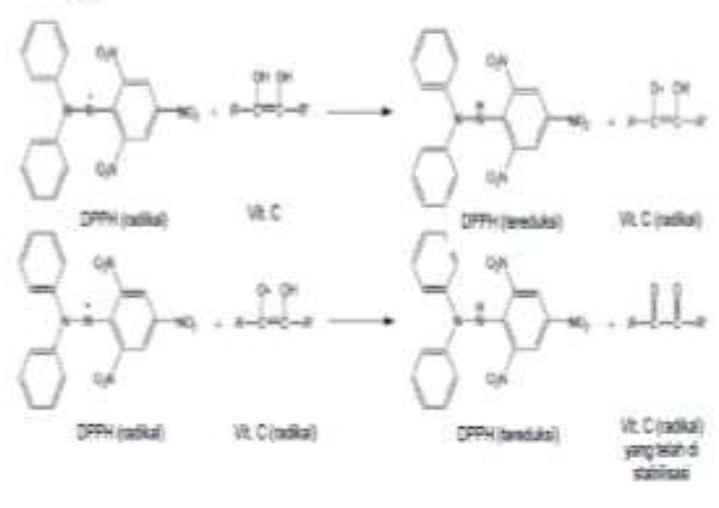

Gambar 1.3 Reaksi asam askorbat dengan DPPH (Sayuti dkk., 2015). 


\section{KESIMPULAN}

Bedasarkan hasi nilai $\mathrm{IC}_{50}$ ekstrak buah mengkudu, kelor dan kedondong hutan, mengkudu mempunyai nilai $\mathrm{IC}_{50}$ paling kecil dengan nilai $22.95 \mu \mathrm{g} / \mathrm{mL}$, hal ini dikarenakan terdapat kadungan asam askorbat pada buah mengkudu yang tidak dimiliki tanaman lainnya.

\section{UCAPAN TERIMA KASIH}

Penulis mengucapkan terima kasih kepada semua pihak yang telah membantu penelitian ini.

\section{DAFTAR PUSTAKA}

Amarowicz, R., Pegg, R.B., RahimiMoghaddam, P., Barl, B. and Weil, J.A. 2004. Free-radical Scavenging Capacity and Antioxidant Activity of Selected Plant Species From The Canadian Prairies. Jurnal Food Chem. Vol. 84. Hal. 551-562.

Anwar, K. Trisyasmono, L. 2016. Kandungan Total Fenolik, Total Flavonoid, dan Aktivitas Antioksidan Ekstrak Etanol Buah Mengkudu (Morinda citrifolia $\mathrm{L}$ ). Jurnal Pharmasciense. Vol. 3(1). Hal. 83-92

Benzie, I.F. and Strain, J.J.1996. The ferric reducing ability of plasma (FRAP) as a measure of "antioxidant power": the FRAP assay. Jurnal Anal Biochem. Vol. 239 (1). Hal 70-6.

Cahyana, M. Taufik, E. 2002. Isolasi Senyawa Antioksidan Kulit Batang Kayu Manis (Cinnamomum burmanii). Vol.3 (2). Hal. 50-58

Depkes RI. 2000. Parameter Standar Umum Tumbuhan Obat. Jakarta: Departemen Republik Indonesia. Hal: 20.

Kumaran, A., and Karunakaran, R.J. 2005. Antioxidants Activities of Methanol Extracts of Five (Phyllanthus urinaria. Jurnal Food and Chemical Toxicology. Vol. 46. Hal. 2485-2492.

Li, P., Huo, L., W., Lu, R., Deng, C., Liu, L., Deng, Y., Guo, N., Lu, C. and He, C. 2011. Free Radical Scavenging Capacity, Antioxidant Activity and Phenolic Content of (Pouzolzia zeylanica).College of Pharmacy, J. Serb. Chem. Soc. Vol.76 (5). Hal.709-717.

Molineux, P. 2004. The Use of The Stable Free Radical Diphenylpicrylhydrazyl (DPPH) for Estimating Antioksidan Activity. Songklanakarin J.Sci. Techol. Vol.26 (2). Hal. 211-219

Pitojo, S., dan Sumiati. 2005. Cincau: Cara Pembuatan dan Variasi Olahan. Jakarta : Agromedia Pustaka.

Sayuti, K., Rina, Y. 2015. Antioksidan Alami dan Sintetik. Padang: Andalas University Press. Hal. 68, 77

Tryasmono, L. Anwar, K. 2016. Kandungan Total Fenolik, Total Flavonoid, dan Aktivitas Antioksidan Ekstrak Etanol Buah Mengkudu (Morinda citrifolia $\mathrm{L}$ ). Jurnal Pharmasaence. Vol.8(1). Hal. 8392. 